\title{
Maturation of the pituitary-gonadal system in the male rat
}

\author{
B. E. Piacsek and M. P. Goodspeed \\ Department of Biology, Marquette University, Milwaukee, Wisconsin 53233, U.S.A.
}

\begin{abstract}
Summary. Serum FSH and testosterone concentrations reached maximum levels between 35 and 45 days of age, which coincided with the appearance of mature spermatozoa in the majority of seminiferous tubules. Spermatozoa were not observed in sections of the urethra until the age of 46 days. Serum LH concentrations were low $(5-6 \mathrm{ng} / \mathrm{ml})$ before Day 25 , became highly variable $(12-57 \mathrm{ng} / \mathrm{ml})$ between Days 25 and 53 and remained consistently above $35 \mathrm{ng} / \mathrm{ml}$ thereafter. Serum prolactin levels rose significantly between 30 and 43 days of age. Maximum prolactin levels coincided with the start of accelerated growth in the prostate and seminal vesicle glaids. Testicular weights relative to body weight reached a plateau by 35 days of age, while relative pituitary and adrenal weights decreased throughout the study period. It is suggested that spermatogenesis is not complete until FSH and testosterone reach maximum levels, while prolactin may be involved in the stimulation of accessory sex organ growth. The pronounced variation in serum LH concentrations during the maturation period may reflect a progressive change in the sensitivity of the hypothalamic-pituitary axis to the negative feedback of gonadal steroids.
\end{abstract}

\section{Introduction}

Post-natal development of the reproductive system in the male rat has been reviewed (McCann, Ojeda \& Negro-Vilar, 1974). Available data indicate disagreement regarding the time-related changes in structural and endocrine variables. A close relationship between circulating FSH levels and testicular development has been demonstrated: there is an increase in both between 20 and 35 days of age and a significant drop in FSH by 50 days of age (Swerdloff, Walsh, Jacobs \& Odell, 1971; McCann et al., 1974; Lee, de Kretser, Hudon \& Wang, 1975). In contrast to these observations, Ojeda \& Ramirez (1972) and Dohler \& Wuttke (1975) found only a gradual increase in FSH levels and failed to show a decline following testicular maturation. Previous results on $\mathrm{LH}$ secretion are also equivocal. Elevated LH levels in the early post-natal period have been reported to drop significantly by Day 15 (Ojeda \& Ramirez, 1972) or Day 28 (Lee et al., 1975). The results of Dohler \& Wuttke (1975) and Goldman, Grazia, Kamberi \& Porter (1971) do not confirm this early elevation. Estimates of circulating LH concentrations after Day 15 may show a steady rise (Swerdloff et al., 1971; Ojeda \& Ramirez, 1972; McCann et al., 1974), no significant change (Dohler \& Wuttke, 1975) or a nadir at Day 28 and a subsequent rise (Lee et al., 1975). Interpretation of previous results is further complicated by the fact that in some studies analysis of results was made only according to chronological age (Dohler \& Wuttke, 1975), while in others endocrine changes were correlated with development of the testes (Lee et al., 1975) and/or accessory sex organs (Swerdloff et al., 1971; Ojeda \& Ramirez, 1972; McCann et al., 1974). Serum prolactin levels have been shown to rise significantly between 20 and 25 days of age (McCann et al., 1974; Dohler \& Wuttke, 1975) and to undergo a second elevation at 50 days (McCann et al., 1974). Testosterone measurements (Lee et al., 1975; Dohler \& Wuttke, 1975) are similar with a slight drop between 20 and 25 days and a subsequent steady rise until maturation. The present study was undertaken to resolve some of the discrepancies noted in the literature by studying the chronological changes in endocrine variables and correlating them with development and growth of the testes and accessory sex glands. 


\section{Materials and Methods}

\section{Animals}

Pregnant rats of the Sprague-Dawley strain were obtained from the Holtzman Co. (Madison, Wisconsin) 2 weeks before the estimated time of parturition. After birth each litter was adjusted to contain 8 young which were reared in a photoperiod of $14 \mathrm{~h}$ light $\left(05: 00-19: 00 \mathrm{~h}, 600 \mathrm{~lm} / \mathrm{m}^{2}\right) /$ day and an ambient temperature of $23 \pm 1{ }^{\circ} \mathrm{C}$. All animals were weaned at 22 days after birth, and the males were housed as 6 to a cage. Purina Laboratory Chow (Ralston Purina Co., St Louis, Missouri) and tap water were provided ad libitum. Starting at 14 days of age, groups of 6-10 rats were killed by decapitation at 1-5 day intervals until Day 79 and on Days 89 and 120. Most frequent sampling was conducted between 35 and 65 days of age.

Serum samples were collected from each animal and stored at $-50^{\circ} \mathrm{C}$ until assay. Before 20 days of age samples from 2 animals were pooled. Pituitary, ventral prostate, seminal vesicle and adrenal glands and testes were removed, trimmed of extraneous tissue and weighed. Testes and portions of the urethra were fixed in Bouin, sectioned at $7 \mu \mathrm{m}$ and stained with haematoxylin and eosin for histological examination. Cross-sections of 10 seminiferous tubules were examined for each animal.

\section{Assays}

Testosterone. Serum samples for the radioimmunoassay were extracted with diethyl ether. Testosterone and $5 \alpha$-dihydrotestosterone were separated by thin-layer chromatography (t.l.c.) by using silica gel GF $254(100 \mu \mathrm{m}$ thickness; E. Merck AG, Darmstadt, West Germany) and a solvent system of iso-octane:ethyl acetate $(3: 2 \mathrm{v} / \mathrm{v})$. Recoveries were estimated by the addition of 1000 c.p.m. $\left[1,2,6,7-{ }^{3} \mathrm{H}\right]$ testosterone (sp. act. $85 \mathrm{Ci} / \mathrm{mmol}$; New England Nuclear, Boston, Massachusetts). Recoveries ranged from 48 to $88 \%$ with an average value of $71 \%$. The antiserum was produced in rabbits against testosterone-11-BSA. Characterization of the antiserum and validity criteria were established before assay of the experimental material. Maximum binding was obtained with incubation for $3.5 \mathrm{~h}$ and this period was always used. At an antibody dilution of $1: 15000,30-35 \%$ of the labelled testosterone was bound in the absence of unlabelled hormone under the assay conditions used. Cross-reactions (Abraham, 1969) with various steroids were: testosterone, $100 \%$; $5 \alpha$-dihydrotestosterone, $37 \%$; $5 \alpha$-androstan-3 $\beta, 17 \beta$-diol, $3.7 \%$; androst-5-ene- $3 \beta, 17 \beta$-diol, $3.5 \%$; androst-

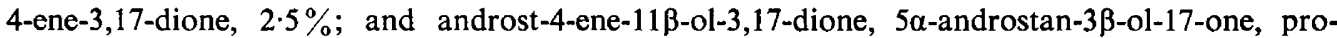
gesterone, $20 \alpha$-hydroxypregn-4-ene-3-one, $17 \alpha$-hydroxyprogesterone, oestradiol-17 $\beta$, oestrone and cholesterol, $\leqslant 0 \cdot 1 \%$. Separation of $5 \alpha$-dihydrotestosterone from testosterone by t.l.c. was estimated by the spotting of $\left[1,2-{ }^{3} \mathrm{H}\right]$ dihydrotestosterone (sp. act. $48 \mathrm{Ci} / \mathrm{mmol}$ : New England Nuclear) with the unlabelled testosterone. Less than $8 \%$ of the counts was recovered in an area of the plates in which more than $99 \%$ (as estimated by radioimmunoassay) of the testosterone was recovered. It was, therefore, assumed that $92 \%$ of the $5 \alpha$-dihydrotestosterone is separated from testosterone by t.l.c. Sensitivity (zero dose plus two standard deviations) ranged from 1.8 to $6.0 \mathrm{pg}$. The linear portion of the curve generally fell between 10 and $300 \mathrm{pg}$. Values which gave more than $86 \%$ or less than $20 \%$ binding were excluded from the results. The intra- and inter-assay variability were calculated as described by Abraham, Swerdloff, Tulchinsky \& Odell (1971) and averaged 8.56 and 17.8\%, respectively. Accuracy of the assay was tested by measurements on aliquots of serum (from castrated adrenalectomized rats) to which known amounts of testosterone had been added. When corrected for recovery, the highest difference between measured and expected values was $15 \%$. Addition of extract from silica gel $\left(2 \times 2 \mathrm{~cm}^{2} \times 100 \mu \mathrm{m}\right.$ thick $)$ to standard doses of testosterone did not produce a significant difference in the percentage binding when compared to identical doses without silica extracts.

\section{Gonadotrophins and prolactin}

Serum FSH and prolactin were measured by radioimmunoassay kits obtained from the National Institute of Arthritis, Metabolism and Digestive Diseases, NIH, Bethesda, Maryland. LH concentrations were measured by the radioimmunoassay described by Niswender, Midgley, Monroe \& 
Reichert (1968). Concentrations of all three hormones were measured and expressed in terms of NIAMDD-RP-1 reference standards. Sensitivities for the assay systems were: FSH, 22-26 ng; LH, $1.2-2.0 \mathrm{ng}$; and prolactin, $0.015-0.075 \mathrm{ng}$. Intra-assay and inter-assay variabilities for FSH, $\mathrm{LH}$ and prolactin were $10 \cdot 2,9 \cdot 9,8 \cdot 3 \%$ and $10 \cdot 1,12 \cdot 2,9 \cdot 3 \%$ respectively. Accuracy for the FSH, LH and prolactin assays was 10,12 and $19 \%$ respectively.

\section{Statistical analyses}

Assay data were assessed by a computer programme. Age-related changes in organ weights and in hormone concentrations were resolved by analysis of variance or Student's $t$ test.

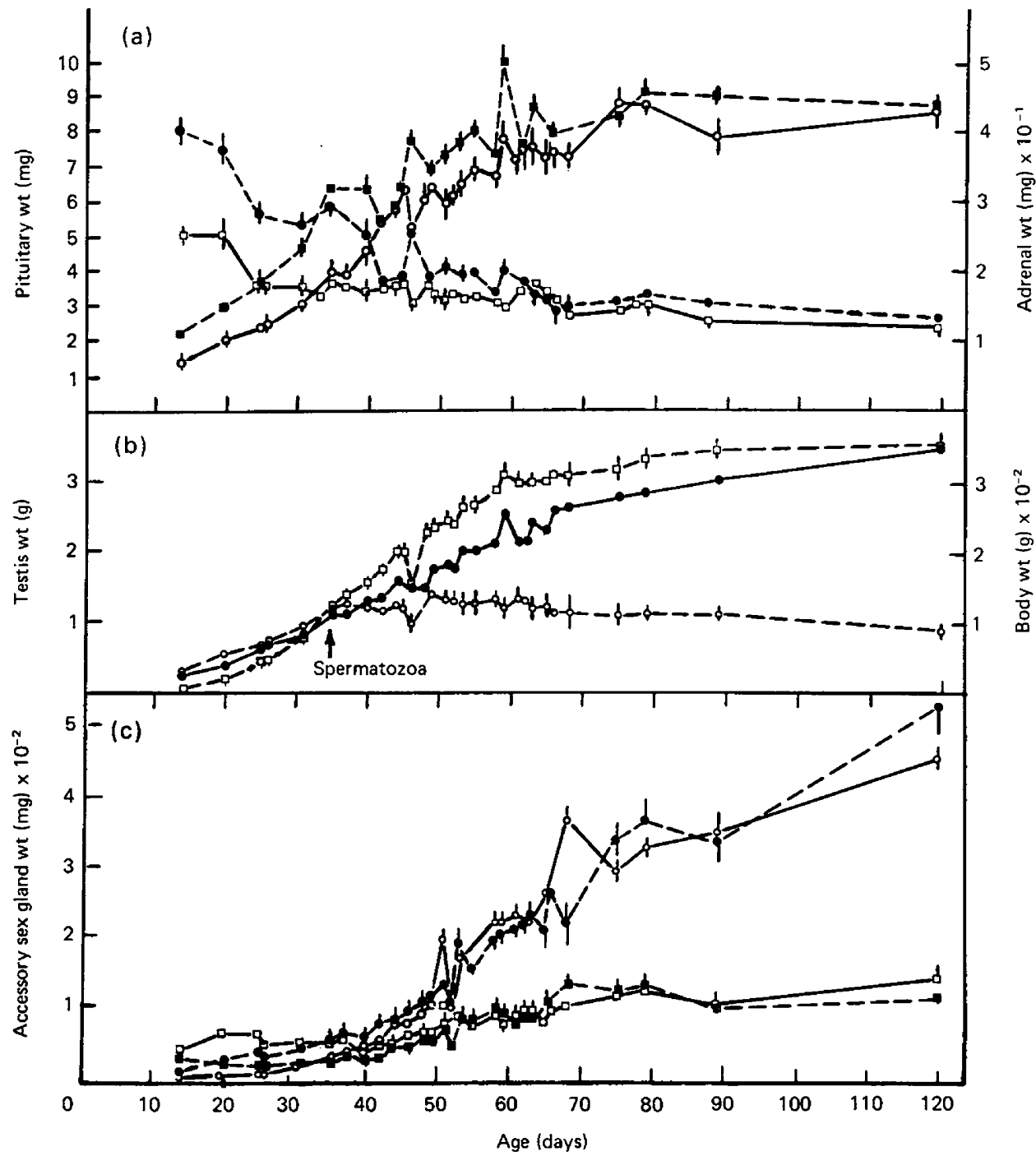

Text-fig. 1. Changes (mean \pm s.e.m.) in body weight and weights of reproductive organs of male rats (6-10/group) during sexual maturation. Relative weights are expressed as per $100 \mathrm{~g}$ body weight. (a) Absolute $(O)$ and relative $(\square)$ pituitary $(-)$ weight; absolute $(\square)$ and relative $(\bullet)$ adrenal (---) weight.

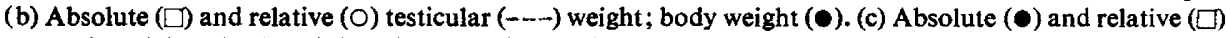
prostatic weight; absolute $(O)$ and relative $(\square)$ seminal vesicle weight. 


\section{Results}

\section{Structural development}

The growth of various organs is shown in Text-fig. 1 as absolute weight and in relation to body weight. Absolute testis weight remained unchanged after 75 days of age, but no significant increase in relative testicular weight occurred after 37 days.

\section{Appearance of spermatozoa}

Spermatozoa were seen in the seminiferous tubules of some animals as early as 31 days of age and all rats had spermatozoa in at least $10 \%$ of the tubules examined by Day 35 and in more than $80 \%$ of tubules by Day 42 . No spermatozoa were found in the urethra before 46 days of age. Although more spermatozoa were seen between 51 and 58 days, some fully mature rats lacked spermatozoa in urethral sections.

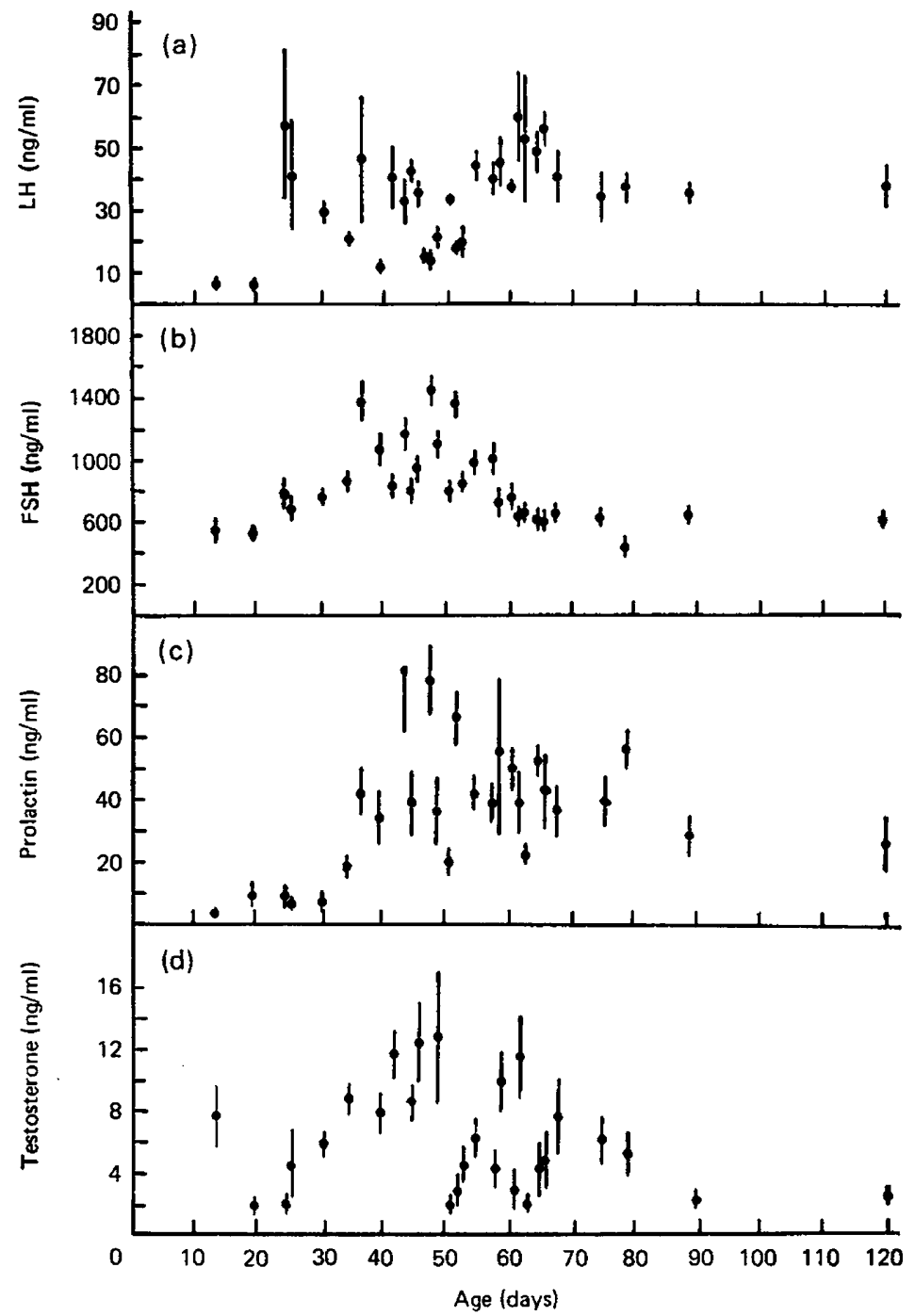

Text-fig. 2. Serum concentrations (mean \pm s.e.m.) of (a) LH, (b) FSH, (c) prolactin and (d) testosterone in male rats (6-10/group) during sexual maturation. Spermatozoa appeared in the testis form Day 35 onwards. 
Hormone levels (Text-fig. 2)

Serum LH concentrations were very low $(5-6 \mathrm{ng} / \mathrm{ml})$ on Days 14 and 20 . Between Days 25 and 53 they were significantly higher $(P<0.01)$, but the values were highly variable. After Day 55 , the serum LH concentrations remained consistently high $(>35 \mathrm{ng} / \mathrm{ml})$.

FSH concentrations in serum were low $(<600 \mathrm{ng} / \mathrm{ml})$ on Days 14 and 20 , rose significantly $(P<0.01)$ to values over $1200 \mathrm{ng} / \mathrm{ml}$ by Day 37 and remained elevated $(800-1400 \mathrm{ng} / \mathrm{ml})$ until 58 days of age. By Day 62 , FSH concentrations had dropped significantly $(P<0.01)$ to $650 \mathrm{ng} / \mathrm{ml}$ and remained at about this level thereafter.

Serum prolactin concentrations did not change between 14 and 30 days and remained below $10 \mathrm{ng} / \mathrm{ml}$. At 35 days of age, concentrations rose sharply and significantly $(P<0.01)$ to a peak level of $82 \mathrm{ng} / \mathrm{ml}$ on Day 44, followed by a gradual decline to adult daytime levels (Hostetter \& Piacsek, 1977) of 20-40 ng/ml by Days 89 and 120. Like the LH and FSH concentrations, serum levels of prolactin were most variable between Days 35 and 74 .

Serum testosterone concentrations dropped significantly $(P<0.01)$ between Days 14 and 20, and then rose consistently from $4.2 \mathrm{ng} / \mathrm{ml}$ on Day 26 to a peak value of $12.8 \mathrm{ng} / \mathrm{ml}$ on Day 49 . Between Days 50 and 75 testosterone concentrations varied between $2 \cdot 2$ and $11.9 \mathrm{ng} / \mathrm{ml}$.

\section{Discussion}

The results obtained in the present study provide a comprehensive and synchronous evaluation of endocrine and structural changes during the maturation period of the male rat. Maximum serum FSH concentration at about 35 days of age followed by a subsequent decline are in good agreement with the findings of McCann et al. (1974) and Swerdloff et al. (1971). The present data also confirm earlier observations (McCann et al., 1974) that the relative weight of the testes plateaus at about the same time that maximum FSH levels are reached. However, spermatozoa were observed in the lumina of the seminiferous tubules considerably earlier in the present study (from Day 35) than has been reported by others (Swerdloff et al., 1971; Lee et al., 1975).

Serum testosterone levels increased significantly at least 10 days before the appearance of spermatozoa in the seminiferous tubules. The drop of serum testosterone concentrations between 20 and 25 days of age is in agreement with the observations of Lee et al. (1975) and Dohler \& Wuttke (1975). The rise found in the present study is more pronounced than that found by Lee et al. (1975) and appears similar to that reported by Dohler \& Wuttke (1975). The absolute values of testosterone concentration are higher than those reported previously (Lee et al., 1975) during sexual maturation, although similarly high average values have been observed in adult male rats (Bartke, Steele, Musto \& Caldwell, 1973) in which daily fluctuations in the same animal can range from 1.8 to $15 \cdot 3 \mathrm{ng} / \mathrm{ml}$. We do not know the reasons for this discrepancy: our blank values ranged only from 0 to $5 \%$ of the total testosterone measured, but differences in environmental conditions or the time of sample collection may be at least partly responsible. Daily rhythms (Kinson \& Liu, 1973a; Hostetter \& Piacsek, 1977) and seasonal variations (Kinson \& Liu, 1973b) in serum testosterone concentrations have been reported.

Perhaps the most difficult to explain are the serum LH concentrations. Although a significant elevation was found between 20 and 25 days of age, the $\mathrm{LH}$ values fiuctuated between $12 \mathrm{and} 59 \mathrm{ng} / \mathrm{ml}$, close to the range of values found by Dohler \& Wuttke (1975), and did not remain consistently in the adult range $(35-60 \mathrm{ng} / \mathrm{ml})$ until after Day 54 . Not only are the variations between daily means substantial, but the variation between animals in the same group is greater between Days 25 and 53 than in the adult or early post-natal animal. There may be at least two possible explanations for this variability. First, individual animals could reach maturity at different times despite identical chronological age, but this possibility is not supported by the uniform standard errors of the organ weights at these ages or the narrow time range during which spermatozoa appear in the testes. Secondly, $\mathrm{LH}$ values may undergo considerable day-to-day variations within the same animal during the early maturation period. The feedback sensitivity of the hypothalamic-pituitary system may fluctuate until a new adult 'set point' is reached. 
The elevation in $\mathbf{L H}$ secretion occurs at a time when testosterone concentrations are reduced (20-25 days). Since testosterone concentrations before this age were elevated despite low serum LH concentrations, it is possible that most of the testosterone before 20 days of age is secreted by the adrenal cortex rather than the gonads. Evidence for this has been presented by Gupta, Zarzycki \& Rager (1975). A drop in adrenal androgen secretion and a subsequent rise in LH secretion may be one of the mechanisms responsible for activation of the testes.

The present study also supports the hypothesis expressed by Odell, Swerdloff, Jacobs \& Hescox (1973) and Odell, Swerdloff, Bain, Wollesen \& Grover (1974) that sexual maturation is, at least partly, the result of FSH-induced testicular sensitivity to LH. FSH and testosterone concentrations appear to rise and reach peak levels simultaneously and FSH may stimulate the development of LH receptors in testicular tissue (Ketelslegers, Hsueh, Hetzel \& Catt, 1976; Chen, Payne \& Kelch, 1976).

We did not find a second rise of prolactin concentrations at about Day 50 as reported by McCann et al. (1974), but our results demonstrate a notable correlation between accessory sex gland development and serum prolactin concentrations. Although testosterone levels rise significantly between 20 and 35 days of age, the relative weight of the ventral prostate and seminal vesicles does not increase until approximately 40 days of age, a time when prolactin values show a sharp rise. Prolactin has been shown to synergize with testosterone in stimulating the growth of the prostate and the seminal vesicles (Segaloff, Steelman \& Flores, 1956; Chase, Geschwind \& Bern, 1957; Von BerswordtWallrabe, Steinbech, Halm \& Elger, 1969) and the uptake of zinc into the dorsolateral prostate (Moger \& Geschwind, 1972). Prolactin may also enhance testosterone secretion from the testes as suggested by studies of Hafiez, Lloyd \& Bartke (1972) and Johnson (1974). However, the present results indicate that serum testosterone concentrations increased significantly before any elevation in prolactin levels. It is, therefore, more likely that synergism between prolactin and testosterone affected the accessory sex glands, than that synergism between prolactin and LH affected the testes.

Financial support for this study was provided by the National Institute for Child Health and Human Development under Grant No. HD-04375. We thank the NIAMDD for radioimmunoassay materials, Dr G. D. Niswender, Colorado State University, for antisera for the radioimmunoassay of LH and testosterone; and Dr L. E. Reichert, Emory University, for LH for iodination.

\section{References}

ABRAHAM, G.E. (1969) Solid-phase radioimmunoassay of estradiol-17ß. J. clin. Endocr. Metab. 29, 866-870.

Abraham, G.E., Swerdloff, R., Tulchinsky, D. \& ODELL, W.D. (1971) Radioimmunoassay of plasma progesterone. J. clin. Endocr. Metab. 32, 619-624.

Bartke, A., Steele, R.E., Musto, N. \& Caldwell, B.V. (1973) Fluctuation in plasma testosterone levels in adult male rats and mice. Endocrinology 92, 1223-1228.

Chase, M.D., Geschwind, I.I. \& Bern, H. (1957) Synergistic role of prolactin in response of male rat sex accessories to androgen. Proc. Soc. exp. Biol. Med. 94, 680-683

Chen, Y.I., PAYNe, R.P. \& Kel.h, R.P. (1976) Action of FSH and testosterone (T) on quantity of LH (hCG) receptors and in vitro capacity of testosterone synthesis in the immature rat testis. 58th A. Meeting Endocrine Soc. Endocrinology 98A, Abstr. No. 40, p. 76.

DohleR, K.D. \& WuTTKE, W. (1975) Changes with age in levels of serum gonadotropin, prolactin, and gonadal steroids in prepubertal male and female rats. Endocrinology 97, 898-907.
Goldman, B.D., Grazia, Y.R., KAMBERI, I.A. \& PORTER, J.C. (1971) Serum gonadotropin concentrations in intact and castrated neonatal rats. Endocrinology 88, 771-776.

Gupta, D., ZARzYCKI, J. \& RAGER, K. (1975) Plasma testosterone and dihydrotestosterone in male rats during sexual maturation and following orchidectomy and experimental bilateral cryptorchidism. Steroids 25, 33-42.

Hafiez, A.A., Lloyd, C.W. \& Bartke, A. (1972) The role of prolactin in the regulation of testis function: the effects of prolactin and luteinizing hormone on the plasma levels of testosterone and androstenedione in hypophysectomized rats. $J$. Endocr. 52, 327-332.

Hostetter, M.W. \& Piacsek, B.E. (1977) Patterns of pituitary and gonadal hormone secretion during a 24 hour period in the male rat. Biol. Reprod. 16, $495-498$.

Johnson, D.C. (1974) Temporal augmentation of LH by prolactin in stimulation of androgen production by the testes of hypophysectomized male rats. Proc. Soc. exp. Biol. Med. 145, 610-613. 
Ketelslegers, M.M., Hsueh, A.J.W., Hetzel, W.D. \& CATT, K.J. (1976) Induction of luteinizing hormone (LH) receptors and $\mathrm{LH}$ sensitivity in the immature rat testis by follicle stimulating hormone (FSH). Proc. 5th Int. Congr. Endocr., Abstr. No. 519, pp. 213-213.

Kinson, G.A. \& LiU, C. (1973a) Diurnal variations in plasma testosterone of the male laboratory rat. Horm. Metab. Res. 5, 233-234.

Kinson, G.A. \& LIU, C. (1972b) Diurnal variations in plasma testosterone of the male laboratory rat. $J$. Endocr. 56, 337-341.

LeE, V.W.K., DE KRETSER, D.M., HudSON, B. \& WANG, C. (1975) Variations in serum FSH, LH and testosterone levels in male rats from birth to sexual maturity. J. Reprod. Fert. 42, 121-126.

McCann, S.M., OJeda, S. \& Negro-Vilar, A. (1974) Sex steroid, pituitary and hypothalamic hormones during puberty in experimental animals. In Control of the Onset of Puberty, pp. 1-31. Eds M. M. Grumbach, G. D. Grave \& F. E. Mayer. Wiley, New York.

MOgeR, W.H. \& GeSChWIND, I.I. (1972) The action of prolactin on the sex accessory glands of the male rat. Proc. Soc. exp. Biol. Med. 141, 1017-1021.

Niswender, G.D., Midgley, A.R., Monroe, S.E. \& REICHERT, L.E. (1968) Radioimmunoassay for rat luteinizing hormone with antiovine. LH serum and ovine LH ${ }^{131}-1$. Proc. Soc. exp. Biol. Med. 128, 807811.

Odell, W.D., SWerdlofF, R.S., JACOBS, H.S. \& Hescox, M.A. (1973) FSH induction of sensitivity to LH: one cause of sexual maturation in the male rat. Endocrinology 92, 160-165.

Odell, W.D., Swerdloff, R.S., Bain, J., Wollesen, F. \& Grover, P.K. (1974) The effect of sexual maturation on testicular response to $\mathrm{LH}$ stimulation of testosterone secretion in the intact rat. Endocrinology 95, 1380-1384.

Ojeda, S.R. \& Ramirez, V.D. (1972) Plasma level of $\mathrm{LH}$ and $\mathrm{FSH}$ in maturing rats: response to hemigonadectomy. Endocrinology 90, 466-472.

Segaloff, A., Steelman, S.L. \& Flores, A. (1956) Prolactin as a factor in the ventral prostate assay for luteinizing hormone. Endocrinology 59, 233240.

SWerdloff, R.S., Walsh, P.C., Jacobs, H.S. \& Odell, W.D. (1971) Serum LH and FSH during sexual maturation in the male rat: effect of castration and cryptorchidism. Endocrinology 88, 120-128.

Von Berswordt-Wallrabe, R., Steinbech, H., Halm, J.D. \& Elger, W. (1969) Prolactin and the ventral prostate gland in juvenile rats. Experientia 25, 533534.

Received 21 February 1977 